University of Nebraska - Lincoln

DigitalCommons@University of Nebraska - Lincoln

USDA Wildlife Services - Staff Publications

U.S. Department of Agriculture: Animal and Plant Health Inspection Service

2009

\title{
Regional assessment on influence of landscape configuration and connectivity on range size of white-tailed deer
}

\author{
W. David Walter \\ Colorado State University \\ Kurt C. VerCauteren \\ USDA-APHIS-Wildlife Services, kurt.c.vercauteren@usda.gov \\ Henry Campa III \\ Michigan State University \\ William R. Clark \\ lowa State University \\ Justin W. Fischer \\ USDA/APHIS/WS National Wildlife Research Center, Justin.w.fischer@aphis.usda.gov
}

See next page for additional authors

Follow this and additional works at: https://digitalcommons.unl.edu/icwdm_usdanwrc

Part of the Environmental Sciences Commons

Walter, W. David; VerCauteren, Kurt C.; Campa, Henry III; Clark, William R.; Fischer, Justin W.; Hygnstrom, Scott E.; Mathews, Nancy E.; Nielsen, Clayton K.; Schauber, Eric M.; Van Deelen, Timothy R.; and Winterstein, Scott R., "Regional assessment on influence of landscape configuration and connectivity on range size of white-tailed deer" (2009). USDA Wildlife Services - Staff Publications. 843.

https://digitalcommons.unl.edu/icwdm_usdanwrc/843

This Article is brought to you for free and open access by the U.S. Department of Agriculture: Animal and Plant Health Inspection Service at DigitalCommons@University of Nebraska - Lincoln. It has been accepted for inclusion in USDA Wildlife Services - Staff Publications by an authorized administrator of DigitalCommons@University of Nebraska - Lincoln. 


\section{Authors}

W. David Walter, Kurt C. VerCauteren, Henry Campa III, William R. Clark, Justin W. Fischer, Scott E. Hygnstrom, Nancy E. Mathews, Clayton K. Nielsen, Eric M. Schauber, Timothy R. Van Deelen, and Scott R. Winterstein 


\title{
Regional assessment on influence of landscape configuration and connectivity on range size of white-tailed deer
}

\author{
W. David Walter · Kurt C. VerCauteren - Henry Campa III • \\ William R. Clark · Justin W. Fischer · Scott E. Hygnstrom • \\ Nancy E. Mathews - Clayton K. Nielsen - Eric M. Schauber • \\ Timothy R. Van Deelen $\cdot$ Scott R. Winterstein
}

Received: 23 February 2009/ Accepted: 2 June 2009

(C) United States Department of Agriculture/Animal Plant Health Inspection Service/Wildlife Services 2009

\begin{abstract}
Variation in the size of home range of white-tailed deer (Odocoileus virginianus) has broad implications for managing populations, agricultural damage, and disease spread and transmission. Size of home range of deer also varies seasonally because plant phenology dictates the vegetation types that are used as foraging or resting sites. Knowledge of the
\end{abstract}

W. D. Walter $(\bowtie)$

Colorado Cooperative Fish and Wildlife Research Unit, Colorado State University, 201 Wagar Buildling, 1484 Campus Delivery, Fort Collins, CO 80523, USA e-mail: WDavid.Walter@colostate.edu

W. D. Walter

United States Department of Agriculture, Animal and Plant Health Inspection Services, National Wildlife Research Center, 4101 LaPorte Ave., Fort Collins, CO 80521, USA

\section{K. C. VerCauteren · J. W. Fischer}

United States Department of Agriculture,

Animal and Plant Health Inspection Services,

Wildlife Services, National Wildlife Research Center,

4101 LaPorte Ave., Fort Collins, CO 80521, USA

H. Campa III · S. R. Winterstein

Michigan Agricultural Experiment Station and Department of Fisheries and Wildlife, Michigan State University, Room 13 Natural Resources, East Lansing, MI 48824-1222, USA

W. R. Clark

Ecology, Evolution, and Organismal Biology, Iowa State University, 253 Bessey Hall, Ames, IA 50011, USA landscape configuration and connectivity that contributes to variation in size of home range of deer for the region is needed to fully understand differences and similarities of deer ecology throughout the Midwest. We developed a research team from four Midwestern states to investigate how size of home range of deer in agro-forested landscapes is

\author{
S. E. Hygnstrom \\ School of Natural Resources, University of Nebraska, \\ 415 Hardin Hall, Lincoln, NE 68583-0974, USA \\ N. E. Mathews \\ Gaylord Nelson Institute for Environmental Studies, \\ University of Wisconsin-Madison, 115E Science Hall, \\ 550 North Park Street, Madison, WI 53706, USA \\ C. K. Nielsen · E. M. Schauber \\ Cooperative Wildlife Research Laboratory \\ and Department of Zoology, \\ Southern Illinois University, Carbondale, \\ IL 62901, USA \\ T. R. Van Deelen \\ Department of Forest and Wildlife Ecology, \\ University of Wisconsin-Madison, \\ 1630 Linden Dr., Madison, WI 53706-1568, \\ USA
}


influenced by variations in landscape characteristics that provide essential habitat components. We found that for resident female deer, annual size of home range in Illinois $\left(\right.$ mean $\left.=0.99 \mathrm{~km}^{2}\right)$, Michigan $\left(\right.$ mean $\left.=1.34 \mathrm{~km}^{2}\right)$, Nebraska $\left(\right.$ mean $\left.=1.20 \mathrm{~km}^{2}\right)$, and Wisconsin $\left(\right.$ mean $=1.47 \mathrm{~km}^{2}$ ) did not differ across the region $\left(F_{3,175}=0.42, P=0.737\right)$, but differences between agricultural growing and nongrowing periods were apparent. Variables influencing size of home range included: distance to forests, roads, and urban development from the centroid of deer home range, and percent of crop as well as four landscape pattern indices (contrast-weighted edge density, mean nearest neighbor, area-weighted mean shape index, and patch size coefficient of variation). We also identified differences in model selection for four landscapes created hierarchically to reflect levels of landscape connectivity determined from perceived ability of deer to traverse the landscape. Connectivity of selected forested regions within agro-forested ecosystems across the Midwest plays a greater role in understanding the size of home ranges than traditional definitions of deer habitat conditions and landscape configuration.

Keywords Anthropogenic - Connectivity · Home range - Landscape pattern indices . Odocoileus virginianus . White-tailed deer

\section{Introduction}

Studies on the ecology of white-tailed deer (Odocoileus virginianus) typically address population demographics or movements with implications specific to that study area (VerCauteren and Hygnstrom 1998; Grund et al. 2002; Storm et al. 2007). Research addressing a regional assessment of deer populations has practical implications to both biological and sociological issues commonly addressed by resource agencies. For example, deer populations have been implicated in human injuries/fatalities through motor vehicles collisions (Connelly et al. 1987; Stout et al. 1993), depredation to agricultural crops and ornamental plantings (Decker and Gavin 1987; Campa et al. 1997), and illness through the transmission of Lyme disease (Connelly et al. 1987; Deblinger et al. 1993). The spread and transmission of bovine tuberculosis and chronic wasting disease in free-ranging white-tailed deer has been linked to deer populations in adjacent states throughout the Midwest (Schmitt et al. 1997; Miller et al. 2003; Blanchong et al. 2006). State boundaries are not followed by deer so to determine the effect that deer have on infectious disease transmission (Slingenbergh et al. 2004; Wobeser 2006), regional assessment of deer populations are needed in North America.

Researchers may logically wonder if the relative composition and configuration of forests, agricultural lands, and residential communities influence deer habitat use, population abundance, and demographic processes. For example, a regional assessment throughout the Midwest documented that maximum dispersal distance for yearling male deer was greater in areas with less forested cover (Long et al. 2005). This would suggest that the distance deer migrate or disperse is directly related to the configuration and connectivity of forested landscape in a region. Furthermore, deer respond to habitat change (Walter et al. 2009) and transmission of disease has been linked to landscape heterogeneity (Conner and Miller 2004) and these patterns would be dependent upon configuration and connectivity of preferred deer habitat (i.e., forested cover; Gladfelter 1984).

Although there is ample literature on ungulate ecology at single study sites within states, researchers have only recently begun to develop analyses on ungulate behavior, habitat use, and population dynamics at the landscape- or region-level (Kie et al. 2002; Anderson et al. 2005; Said and Servanty 2005). These questions surrounding deer ecology and their use of diverse landscapes translates into important sociological concerns, particularly because deer are often viewed as locally abundant (sensu Caughley 1981) in many regions of the United States (e.g., Warren 1997; Kilpatrick et al. 2001; O'Brien et al. 2006). Analysis of data across regions for white-tailed deer are limited but researchers have documented various landscape variables that were correlated with the size of home range and movements of ungulates at local and landscape levels (Kie et al. 2002; Anderson et al. 2005; Felix et al. 2007). The focus is often on the composition and configuration of landscape variables with sharply contrasting structure, such as forests within landscapes dominated by grass or crop. For example, Kie et al. (2002) found that correlation of some landscape variables (e.g., mean shape index of habitat patches) occurred at large spatial scales (i.e., 
radii of 2,000-m as buffer around deer location) but not at smaller spatial scales (i.e., radii $\leq 1,000-\mathrm{m}$ as buffer around deer location) for mule deer (O. hemionus) in California. Forage biomass and size of home range for elk (Cervus elaphus) were inversely correlated in Alberta and Wisconsin but positively correlated in Wyoming (Anderson et al. 2005). Anderson et al. (2005) found a positive relationship between percent forest cover and home-range size in elk but, similar to Kie et al. (2002), this relationship only occurred at larger spatial scales (i.e., radii of 3,000-m as buffer around elk location).

While buffers around locations or centroids of home range can provide regional assessment over various spatial scales, relationships were found to be dependent on buffer size. Therefore, regional assessment of ungulate use of habitats should consider the influence that different landscape patterns have on movements and home-range size. These issues could be more adequately addressed by using a similar scale of study (i.e., home range) while changing grain size (i.e., landscape configuration and connectivity). Response of organisms to these changes in landscape configuration and connectivity has not been assessed and can help determine the influence that habitat change may have on an organism's use of the landscape it occupies. Assessment of deer populations across regions (e.g., Midwest agricultural region; Gladfelter 1984) is needed for understanding deer use of specific landscapes and how variability or changing habitat conditions within landscapes could influence range size.

A regional research collaboration from four states provided us with a unique opportunity to quantify how landscape variables and configuration may influence size of home range of deer in the Midwest (NCRA 2008). Our study sites across the Midwest included a gradient of mixed agricultural crops and forested cover types. At one extreme, forest patches in the Nebraska study site were imbedded within a matrix of row crop agriculture (high contrast). At the other extreme, the Wisconsin study site was within a region of more completely interspersed forest and agriculture patches that were similar (low contrast). Study sites in Michigan and Illinois were intermediate between the extremes, with Illinois representing the greatest degree of exurban development (i.e., 0.062-0.247 housing units per ha; Theobald 2001). Our research objectives were to: (1) quantify size of home range for deer by season and across states, (2) determine the influence of landscape variables on size of home range for deer, (3) determine the best models of landscape variables that influence size of home range of deer during crop growing and nongrowing seasons because size of home range would be expected to vary by phenological season, and (4) determine the influence of landscape connectivity on the size of home range of deer since landscape variables would be expected to vary depending on proximity and juxtaposition of various cover types that provide habitat components for deer.

\section{Methods}

Study sites

Seven cover types (water, developed, forest, shrub, grassland, cropland, and emergent wetland vegetation) were delineated for all study sites within the $100 \%$ minimum convex polygon that encompass locations of all resident (see section on home range for definition of resident) deer at each study site. Specifically, we studied deer in an exurban setting southeast of Carbondale, Illinois, in Jackson and Williamson Counties (Storm et al. 2007; Fig. 1). The

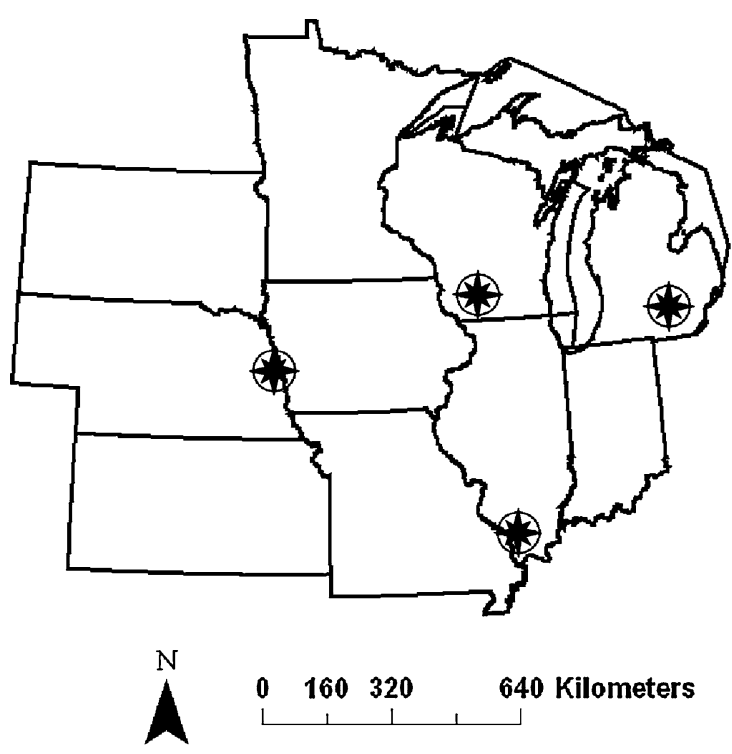

Fig. 1 Map of Midwest region with circled stars used to identify study sites in Illinois, Michigan, Nebraska, and Wisconsin, 2000-2006 
study site encompassed nearly $18 \mathrm{~km}^{2}$ and contained 357 dwellings (20 dwellings $/ \mathrm{km}^{2}$ ) arranged in a clumped distribution (Harden et al. 2005). The study site was a mix of patches of oak (Quercus spp.)hickory (Carya spp.) forest (57\%), hay fields/grasslands $(26 \%)$, and row-crop agriculture (12\%) consisting of primarily soybean (Kjaer et al. 2008).

We studied deer in Washtenaw and Jackson counties in south-central Lower Michigan. The site $\left(826 \mathrm{~km}^{2}\right)$ represented a diversity of land ownership patterns including public and private lands with state recreation and game areas, agricultural lands, homes, and other uses (Hiller 2007; Fig. 1). The study site consisted of conifer (Pinus spp.), maple (Acer spp.), ash (Fraxinus spp.), cherry (Prunus spp.), birch (Betula spp.), and various oaks. Various non-vegetated farmland, row crops, and forage crops made up about $52 \%$ of the study site.

We studied deer at and surrounding the DeSoto National Wildlife Refuge (DNWR), located $30 \mathrm{~km}$ north of Omaha, Nebraska in the Missouri River valley of eastern Nebraska and western Iowa (VerCauteren and Hygnstrom 1998; Fig. 1). The DNWR was $34 \mathrm{~km}^{2}$ that consisted of forest and primary crops of corn and soybeans. Forty percent (1,350 ha) of DNWR consisted of deciduous forest, dominated by mature eastern cottonwood (Populus deltoides). The understory included rough-leafed dogwood (Cornus drummondii), hackberry (Celtis occidentalis), mulberry (Morus rubra), and green ash (Fraxinus pennsylvanica). Poison ivy (Rhus radicans) and common scouring-rush (Equisetum hyemale) dominated the ground layer. Crops such as corn, soybeans, grain sorghum, alfalfa, and a wheat/clover mix were cultivated on a

3-year rotation. The grain sorghum, alfalfa, clover, and $10-16 \%$ of the corn were left standing through the winter as food plots for wildlife (Walter et al. 2009). The density of deer in DNWR was 33 deer/ $\mathrm{km}^{2}$ from 2004 to 2005, based on helicopter surveys.

We studied deer in Iowa and Dane counties in south-central Wisconsin (Skuldt et al. 2008; Fig. 1). Land cover within the study site $\left(544 \mathrm{~km}^{2}\right)$ was predominantly forest intermixed with agriculture that was primarily corn, soybeans, and alfalfa. Dominant tree species are red oak (Quercus rubra), bur oak (Q. macrocarpa), white oak $(Q$. alba), and big-tooth aspen (Populus grandidentata). The density of deer declined from $10 \pm 2$ in 2003 to $7 \pm 1 \mathrm{deer} / \mathrm{km}^{2}$ in
2005 (R.E. Rolley, Wisconsin Department of Natural Resources, unpublished data).

Capture and radiotelemetry

We captured only female deer in all study sites between January 2000 and March 2006 via various methods and attached Very High Frequency or Global Positioning System radiocollars (Storm et al. 2007; Hiller 2007; Skuldt et al. 2008). Age distribution ranged from 1.5 to 5.5 years and was similar across sites because all populations of deer were hunted annually. All capture and handling methods used were approved by associated Institutional Animal Care and Use Committees.

\section{Home range}

We only included deer in our analysis of home range that occupied our study sites year round (resident) and did not migrate or disperse in response to seasonal climate or phenology. We relocated deer during a predefined time frame (i.e., 8-h time intervals) and collected locations throughout a 24-h period (i.e., nocturnal and diurnal locations). To compare size of home ranges of deer across study sites with varying topographic and landscape features (Kie et al. 2002) and sampling protocols, we determined a minimum number of locations needed to reach an asymptote with an area-observation curve for each deer (Odum and Kuenzler 1955; Gese et al. 1990). We only used deer with $\geq 100$ locations to determine minimum number of locations because 100 locations would be an adequate number of locations to represent size of deer home range and to perform our bootstrap procedure (Fuller et al. 2005).

We determined the minimum number of locations using a bootstrap procedure in the Animal Movement Extension of ArcView 3.2 (ArcView; Hooge and Eichenlaub 1997) for each study site. We used ten iterations that had starting sample sizes of 30 in increments of 20 until the number of locations for each deer were reached (Anderson et al. 2005). We only included deer that had more than the mean minimum number of locations to generate fixed-kernel estimates of home range. We calculated $95 \%$ fixed-kernel estimates of size of home range (hereafter referred to as home range) for all locations of a deer (annual; Worton 1989; Seaman and Powell 1996) because the 
fixed-kernel method considered density of locations and was more accurate at determining outer boundary areas (i.e., 95\% isopleths) compared with adaptive kernel (Seaman et al. 1999). We determined the amount of smoothing by the least-squares crossvalidation $\left(h_{\mathrm{LSCV}}\right)$ method with the default parameter in the Home Range Extension of ArcView (Worton 1989; Rodgers and Carr 1998).

In addition to annual home range, we defined two phenological seasons based on corn growing seasons obtained from the USDA National Agricultural Statistics Service (United States Department of Agriculture 2002). The two periods based on corn growing seasons were: (1) growing-mean date that $\geq 75 \%$ of corn crops emerged to mean date that $\geq 75 \%$ of corn crops were harvested, and (2) nongrowing - mean date that $\geq 75 \%$ of corn crops were harvested to mean date that $\geq 75 \%$ of corn crops emerged. Mean Julian days from each state from 2000 to 2006 were averaged across all states included in the study to determine period dates.

\section{Anthropogenic variables}

We defined anthropogenic variables as any landscape feature or distance measured to any landscape feature that was created by humans (e.g., distance to roads, percent crop) within the geographic information systems (GIS) environment. We used the national land cover database of 2001 (NLCD) that was created from Landsat 7 imagery to determine land-cover categories for each study site (MRLC 2009). To standardize analyses across the Midwest region, we reclassified land cover from the NLCD into 7 categories: water, developed, forest, shrub, grass, crop, and emergent herbaceous wetland. We extracted the proportions of landcover types from NLCD (e.g., forest, grassland) within each deer home range in ArcView.

We determined the proportion of public to private land in each study site using GIS layers of state and federal land that we acquired and merged into a single GIS layer. We then converted the shapefile to a raster layer of 30-m resolution and extracted the public:private within each deer home range in ArcView.

We defined four categories of housing density in a $1 \times 1-\mathrm{m}$ raster data layer based on reclassification of census block group data from Theobald (2001). We defined housing density as urban $(>2.47$ units per ha), suburban (0.247-2.47 units per ha), exurban
(0.062-0.247 units per ha), and rural $(<0.062$ units per ha; Theobald 2001). We preferred housing unit densities to metropolitan statistical units (i.e., census block groups) because they provide a better measure of urban density and sprawl than simply human density (Theobald et al. 1997; Theobald 2001). We determined the distance $(\mathrm{m})$ from the nearest urban housing density to the home range centroid for each deer to account for the effect of anthropogenic structures on home ranges of deer.

We determined the density of roads $\left(\mathrm{km} / \mathrm{km}^{2}\right)$ within each deer home range for all roads (i.e., dirt/ gravel, 2- to 8-lane roads and highways) as a measure of human disturbance from road traffic. To assess the potential responses of several factors believed to influence deer behavior and range size, we calculated the distance $(\mathrm{m})$ of variables (e.g., roads, forested cover) from the home range centroid for each deer. We determined the distance $(\mathrm{m})$ from highways (i.e., 4- to 8-lanes) to home range centroid and distance (m) from nearest road (i.e., dirt/gravel, 2- to 4-lanes) to home range centroid for each deer, as major highways may impede travel of some ungulates. We determined the distance $(\mathrm{m})$ from the nearest forested cover type to the home range centroid for each deer as deer rely on forests for escape cover and shelter.

Landscape configuration

Spatial arrangement of vegetation cover types can influence habitat use (Kie et al. 2002; Owen-Smith 2004; Anderson et al. 2005) so we assessed landscape configuration within each deer home range using landscape patterns indices calculated using the Patch Analyst Extension-Fragstats Interface (Fragstats) in ArcView (Elkie et al. 1999). We included structural contrast weights to account for the structural contrasts that occurred among different vegetation types for all possible habitat contrasts with forest and crop (0.75) and grassland and crop (0.2) representing the maximum and minimum structural contrast, respectively (Kie et al. 2002).

Landscape connectivity

We used a hierarchical approach to delineate habitat patches since habitat selection and movements may be based on landscape connectivity as perceived by deer. We used the PatchMorph patch delineation 
algorithm to delineate patches at several grain sizes (Girvetz and Greco 2007). These grain sizes were determined by how we hypothesize that deer perceived the landscape and not an arbitrary spatial scale typically represented by a circle (i.e., buffer with $100 \mathrm{~m}$ radius) around the centroid of the home range or radiolocation (Girvetz and Greco 2007). PatchMorph allows the user to rank the suitability of habitats (i.e., $0-100 \%$ ) or to identify patches as suitable or unsuitable (i.e., 1, 0), thus altering the configuration of landscape patches into contiguous suitable patches.

We assigned suitability values from 0 to 100 to the land-cover categories such that forest-shrub, grassland-herbaceous, emergent-developed, and water had suitability values of $100,50,25$, and 0 , respectively. Although the suitability of cover types would vary by site, we assigned a maximum percent to each category based on researcher experience and previous research on deer. For example, deer are considered a forest-dependent species thus forested habitat would be assigned a value of 100 (Grund et al. 2002; Storm et al. 2007; Hiller 2007). We assigned the developed category a habitat suitability value of 25 because most areas that had development were classified as exurban or rural and use of residential or commercial landscapes by deer, particularly after sunset, has been well documented (Kilpatrick and Spohr 2000; Etter et al. 2002; Storm et al. 2007). We created three grids using an iterative process in PatchMorph by selecting three threshold minimums for gaps (i.e., thin areas of non-suitable habitat) and spurs (i.e., thin areas of suitable habitat) that excluded habitat from patch delineation based on a combination of study-specific parameters (Girvetz and Greco 2007). We selected a mean distance of $400 \mathrm{~m}$ because it represented the mean distance deer in our study typically traversed in a 24-h period. We also used 200 and $600 \mathrm{~m}$ as thresholds for each iteration because these distances encompassed the likely minimum and maximum distance deer would traverse in a $24-\mathrm{h}$ period based on 25 and $75 \%$ quartiles of deer movements. We determined minimum patch area to be 6 ha as indicated by results from Fragstats analyses of our landscape pattern indices within deer home ranges from our study sites. We used the minimum threshold distances traveled by deer (i.e., 200, 400, $600 \mathrm{~m}$ ) to create three reclassified raster-based landscapes in PatchMorph that represented low, medium, and high landscape connectivity from the gap-spur combinations (Fig. 2).

We generated anthropogenic variables and landscape pattern indices within home ranges for each period of study and for each of the four spatial grains that were defined by varying levels of connectivity as perceived by deer that included: (1) anthropogenicanthropogenic variables and associated landscape pattern indices using NLCD categories (Fig. 2a), (2) low-anthropogenic variables from 1 and associated landscape pattern indices representing a low level of connectivity using gaps and spurs of $200 \mathrm{~m}$ in PatchMorph (Fig. 2b), (3) medium-anthropogenic variables from 1 and associated landscape pattern indices representing a medium level of connectivity using gaps and spurs of $400 \mathrm{~m}$ in PatchMorph (Fig. 2c), and (4) high-anthropogenic variables from 1 and associated landscape pattern indices representing a high level of connectivity using gaps and spurs of $600 \mathrm{~m}$ in PatchMorph (Fig. 2d).

\section{Statistical analysis}

For comparison to previous research on size of home range for deer, we evaluated differences in annual size of home range and seasonal home range with a 2way analysis of variance with state and season as an interaction term. We generated seven anthropogenic variables in GIS and 17 landscape pattern indices with Fragstats. Many anthropogenic variables and landscape pattern indices can be highly correlated so we conducted separate simple Pearson correlations between the response variable (i.e., natural log of home-range size) and independent variables as well as between each independent variable in SAS (SAS Institute, Inc., Cary, NC; Johnson et al. 2000; Kie et al. 2002). We used a Bonferroni correction for multiple comparisons to adjust for experiment-wise error rate (Rice 1989). We retained and entered in the model 4 anthropogenic variables and four landscape pattern indices that were highly correlated with size of home range $(r>0.5)$ but were not correlated with each other. These eight independent variables could be compared across multiple sites because they were derived from a standard method (i.e., distance to roads from centroid of the home-range, contrastweighted edge density).

Independent variables for landscape configuration chosen to describe the response variable should rely 
Fig. 2 Spatial grains of analysis for home ranges of female white-tailed deer showing contrasting landscapes in 1 Michigan and 2 Nebraska for a anthropogenic landscape created from the 2001 National Land Cover Database categories. Additional spatial grains created from the 2001 National Land Cover Database using PatchMorph that reclassified grids to represent $\mathbf{b}$ low, c medium, and d) high connectivity as perceived by white-tailed deer (Girvetz and Greco 2007). Note: green reflects forested cover and purple reflects agricultural crops in 1a and $\mathbf{2 a}$
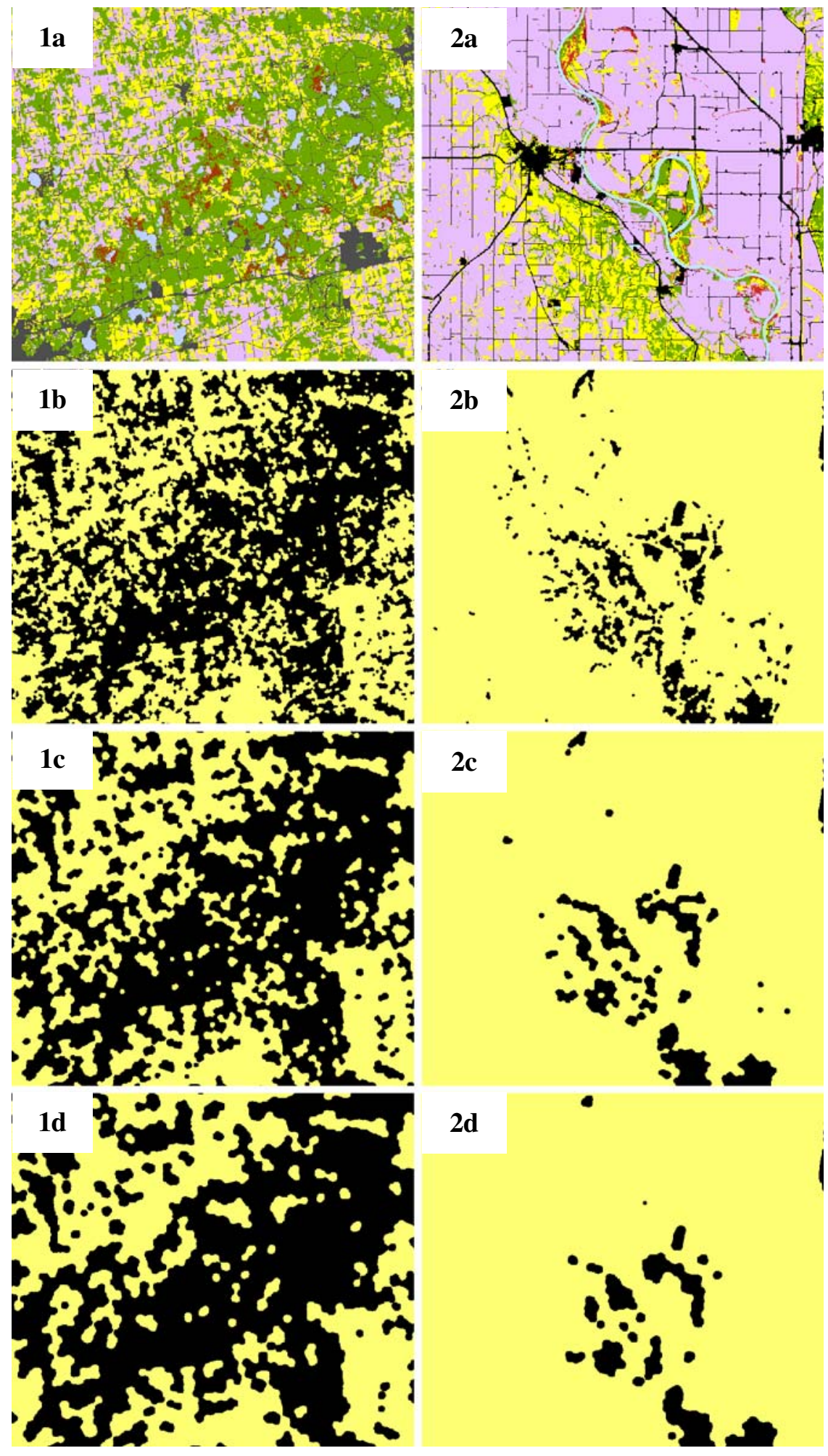

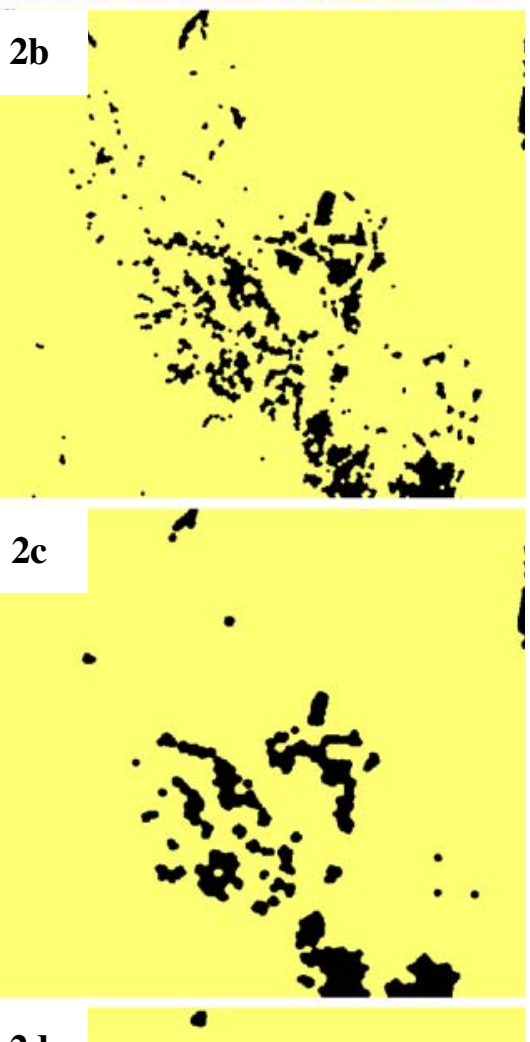

2d

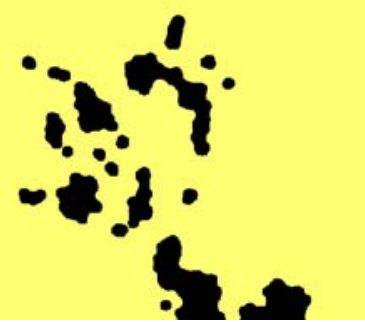

5 Kilometers 
on researcher knowledge of the study organism and is a caveat of the modeling process (Burnham and Anderson 2002). For anthropogenic variables, distance to forest and percent crop are inversely related and distance to roads and urban development were linearly related to size of home range in previous research and have been documented as reliable predictors of range size in deer (Gaughan and DeStefano 2005; Storm et al. 2007). For landscape pattern indices, we selected 4 categories that included: edge (contrast-weighted edge density), patch (patch size coefficient of variation), shape (area-weighted mean shape index), and proximity (mean nearest neighbor) categories that were shown to influence size of home range of deer. We selected contrast-weighted edge density and mean nearest neighbor to describe landscape configuration because more juxtaposed (i.e., high mean nearest neighbor) and high-contrast edges of forested cover types within the home range of deer would decrease size of home range (Kie et al. 2002; Gaughan and DeStefano 2005). We selected patch size coefficient of variation and area-weighted mean shape index to represent indices of fragmented and natural landscapes, respectively (McGarigal and Marks 1995). We would expect patch size coefficient of variation and area-weighted mean shape index to be inversely and positively related to size of home range for deer, respectively.

We used linear regression with Akaike's Information Criterion (AIC; Burnham and Anderson 2002) to select the most parsimonious model among a suite of models for each period of analysis and the four spatial grains of connectivity. We did not use hypothesis testing because we were interested in the independent variables, or combination thereof, that influenced size of home range in deer but not purely differences in variables between sites. At each spatial grain, we conducted modeling procedures separately for annual, growing, and nongrowing periods because independent variables were expected to differ during periods of high (growing) and low (nongrowing) natural forage availability. We assessed a global model that included the eight parameters (four anthropogenic, four landscape pattern indices) previously discussed and an additional 32 models that contained various combinations of those eight parameters using AIC; a model was considered a candidate if it had a $\triangle \mathrm{AIC}<2.0$. We used the natural log of size of home range in all correlation and modeling procedures because the data were less skewed to the tail of the distribution.

\section{Results}

Minimum number of locations needed to determine home range was lowest in Wisconsin $(n=56)$ and highest in Illinois $(n=73$; Table 1$)$. Mean size of annual home range did not differ across the Midwest region $\left(F_{3,175}=0.42, P=0.737\right)$, or during the growing $\left(F_{3,90}=0.38, P=0.770\right)$ and nongrowing $\left(F_{3,99}=0.19, P=0.905\right)$ seasons. We observed no state-season interaction but mean size of home range was smaller during the growing season compared to nongrowing season $\left(F_{1,196}=13.62, P<0.001\right)$.

For annual home range, size of home range was positively correlated with distance to roads $(r=0.247$, $P=0.001)$, distance to forest $(r=0.340, P<0.001)$, percent crop $(r=0.340, P<0.001)$, patch size coefficient of variation $(r=0.611, P<0.001)$, and areaweighted mean shape index $(r=0.706, P<0.001)$. Annual home range was inversely correlated with contrast-weighted edge density $(r=-0.801, P<0.001)$ but not correlated with mean nearest neighbor $(r=$ $-0.007, P=0.920)$. For growing season, home range

Table 1 Mean \pm SE annual and seasonal (growing, nongrowing) 95\% fixed kernel home range size $\left(\mathrm{km}^{2}\right.$ ) for female white-tailed deer in the Midwest, 2000-2006

\begin{tabular}{llllllll}
\hline Site & Min & $N$ & Annual & $N$ & Growing & $N$ & Nongrowing \\
\hline Illinois & 73 & 35 & $0.99 \pm 0.07$ & 11 & $0.70 \pm 0.17$ & 33 & $1.04 \pm 0.09$ \\
Michigan & 66 & 66 & $1.34 \pm 0.17$ & 31 & $0.95 \pm 0.17$ & 28 & $1.48 \pm 0.23$ \\
Nebraska & 62 & 41 & $1.20 \pm 0.16$ & 31 & $1.02 \pm 0.23$ & 18 & $2.74 \pm 1.24$ \\
Wisconsin & 56 & 68 & $1.47 \pm 0.30$ & 24 & $1.06 \pm 0.30$ & 28 & $1.08 \pm 0.12$ \\
\hline
\end{tabular}

Minimum number of radiotelemetry locations needed to estimate home range size determined from bootstrap analysis at each study site (Min) resulted in the sample size $(N)$ of deer used to determine size of home-range 
was positively correlated with distance to roads $(r=0$. 457, $P<0.001)$, patch size coefficient of variation ( $r=0.513, P<0.001)$, area-weighted mean shape index $(r=0.617, P<0.001)$, and mean nearest neighbor $(r=0.444, P<0.001)$. Home range was inversely correlated with contrast-weighted edge density $(r=-0.814, P<0.001)$ but not correlated with distance to forest $(r=0.131, P=0.202)$ and percent crop $(r=0.003, P<0.974)$ during growing season. For nongrowing season, home range was positively correlated with distance to roads $(r=0.374$, $P<0.001)$, distance to forest $(r=0.339, P<0.001)$, percent crop $(r=0.330, P=0.001)$, patch size coefficient of variation $(r=0.540, P<0.001)$, and areaweighted mean shape index $(r=0.560, P<0.001)$. Home range was inversely correlated with contrastweighted edge density $(r=-0.791, P<0.001)$ but not correlated with mean nearest neighbor $(r=0.128$, $P=0.189)$ during nongrowing season.

At the anthropogenic spatial grain (i.e., NLCD categories), the global model had the highest Akaike weights for all three periods of study (i.e., annual, growing, nongrowing) and only one candidate model was selected. The selected model included: contrast weighted edge density, mean nearest-neighbor, areaweighted mean shape index, and patch size coefficient of variation (hereafter referred to as the landscape model; Fig. 3). The global model was the only model selected for the nongrowing season at all 4 spatial grains (Table 2). Within the low connectivity grain, the landscape model had the highest Akaike weights for the annual and growing season (Table 2). The global model had the highest Akaike weights for the annual period in the medium and high connectivity landscapes. However, for the growing season, the landscape model had the highest Akaike weights in the medium and high connectivity landscapes. Akaike weights for the best approximating model during annual and growing season increased from the medium to high connectivity landscape (Table 2).

\section{Discussion}

Comparable home ranges were unexpected considering female deer in our agro-forested study sites across the Midwest occupied a variety of landscapes from exurban (i.e., Illinois; Storm et al. 2007) to rural within a national wildlife refuge (i.e., Nebraska;
VerCauteren and Hygnstrom 1998). Furthermore, home ranges for deer in our study were comparable to those reported for residential communities in Connecticut and South Carolina and an urban park in Illinois (range: $0.33-5.18 \mathrm{~km}^{2}$; e.g., Kilpatrick and Spohr 2000; Henderson et al. 2000; Grund et al. 2002). Although densities of deer ranged from 7 to 33 deer $/ \mathrm{km}^{2}$ in Wisconsin and Nebraska, respectively, the number of deer that migrated or dispersed $(>2 \mathrm{~km})$ from their area of capture was similar in Nebraska and Wisconsin (i.e., 6\%). Disparate densities of deer in Nebraska and Wisconsin with similar dispersal rates and home-range sizes suggest deer densities may not completely explain variability in size of home range. The effects of density of deer on size of home range has been documented, but the disparity from previous research on the relationship between size of home range and density of deer suggested that landscape complexity and productivity (e.g., amount of edge and habitats types) may have greater influence on size of home range and use of crops than density of deer (Ford 1983; Walter et al. 2009).

Although seasonal definitions vary by study, we found that deer in agro-forested ecosystems had larger home ranges during nongrowing period (i.e., late-autumn-winter) compared to growing period. Agriculture within home ranges of deer has resulted in larger winter home ranges than summer home ranges in Minnesota and Illinois (Nixon et al. 1991; Brinkman et al. 2005) potentially from corn fields that provide suitable cover for deer in summer but not winter. Larger home ranges during the nongrowing period could be due to a combination of mild winters not relegating deer to forested cover for thermal protection and lack of forage (e.g., agricultural crops, native vegetation) causing deer to search larger areas for foods in numerous areas. Relatedly, distance to forest was positively correlated with home range during the nongrowing but not growing period suggesting deer searched for suitable forage away from the security of forests during forage-limited periods more often than during periods of high natural-forage availability (i.e., late-spring-summer).

The mean nearest-neighbor was correlated with home range during growing period but not during nongrowing period suggesting deer occupy cover types that are most insular in structure (i.e., small patches with like patches close together) during 


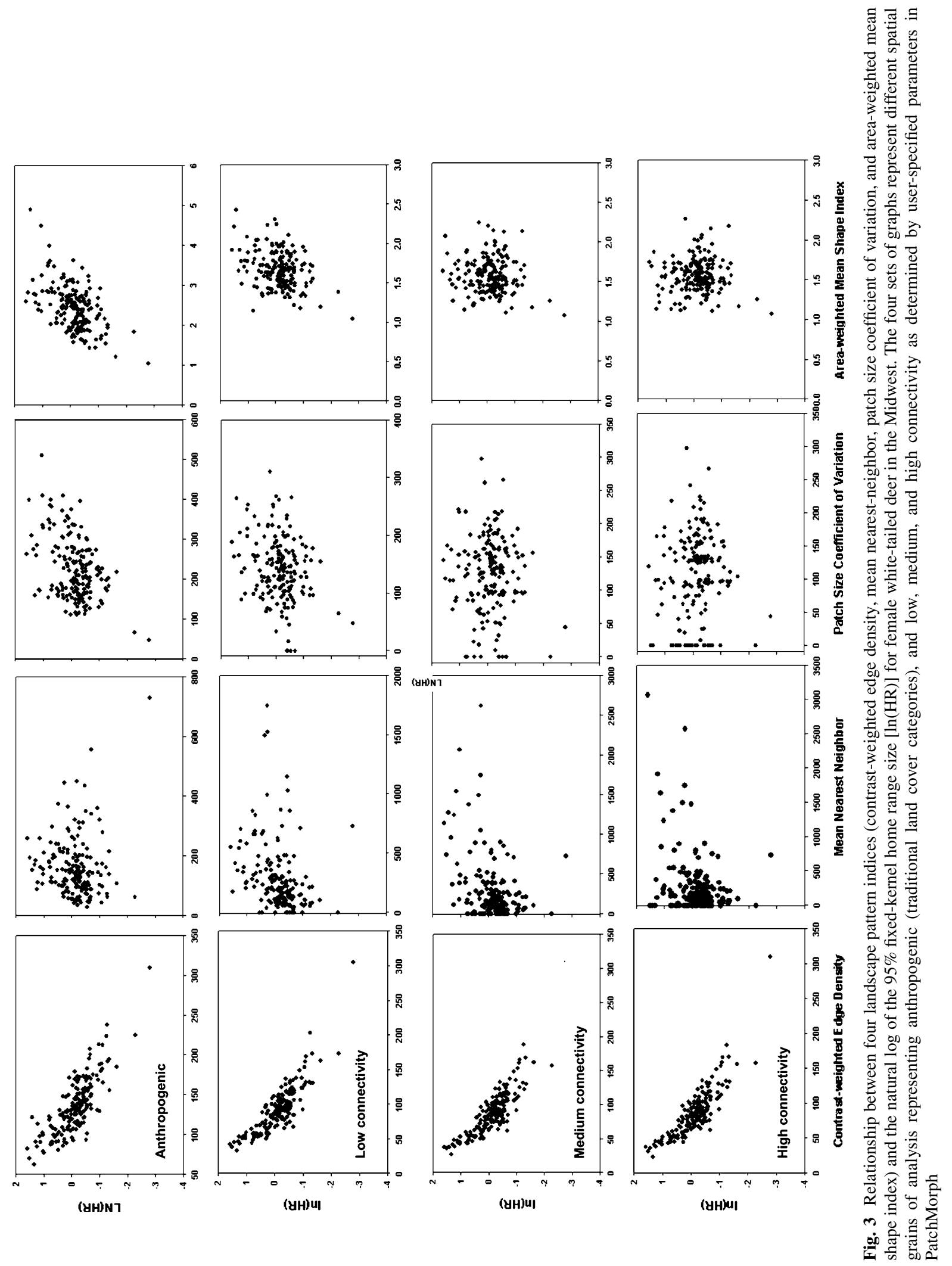




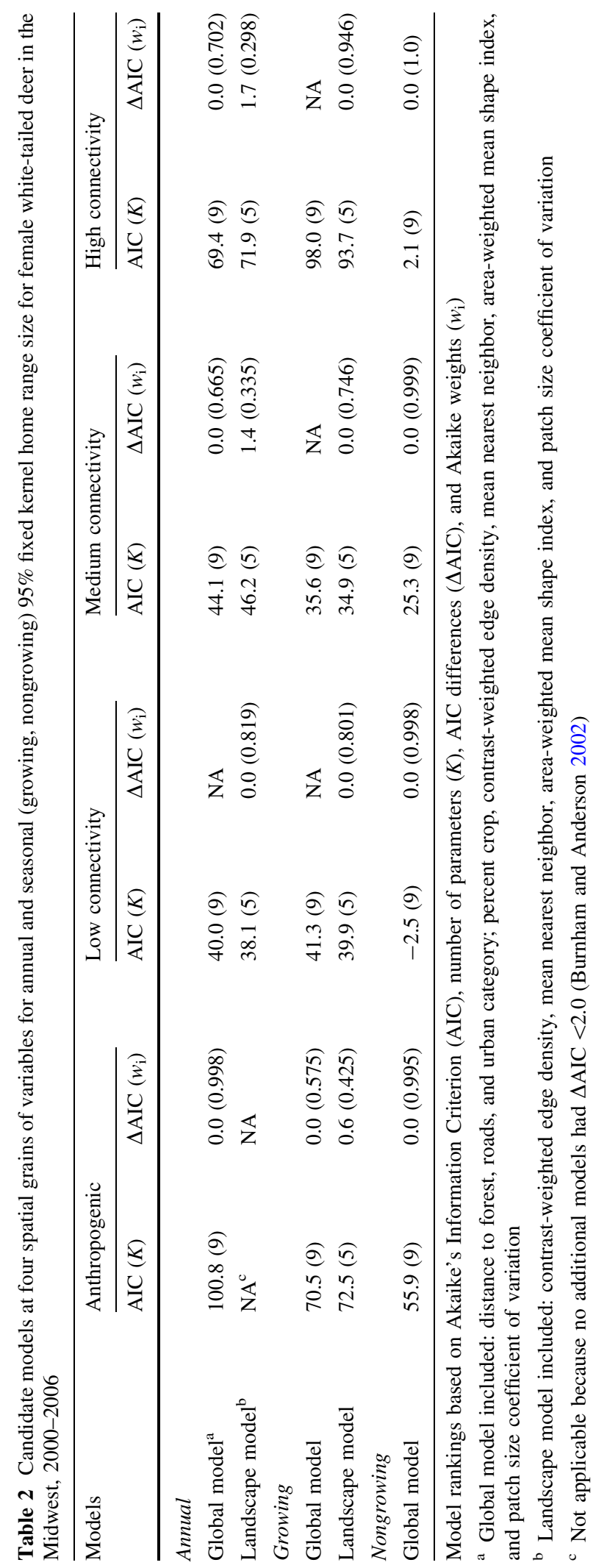


growing period. We expected this, because deer occupy a mixture of forest and grass cover types since they provide ample forages during seasons of high natural-forage availability (Beier and McCullough 1990; Nixon et al. 1991; Brinkman et al. 2005). As forage availability decreases in late-autumn to early-winter, availability of natural-forage declines resulting in a shift of deer home ranges to agricultural fields (Nixon et al. 1991; VerCauteren and Hygnstrom 1998; Brinkman et al. 2005). Large expanses of agricultural and open range landscapes typically have less edge complexity than forested landscapes with scattered forested patches and riparian cover types that are more elongated and narrow (i.e., lower mean patch shapes; Pogue and Schnell 2001; Tscharntke et al. 2005) suggesting potential differences in landscape configuration during seasons of high versus low availability of natural-forage.

Our global model was the best model selected during all periods for anthropogenic spatial grain that included land cover categories we deemed important for understanding size of deer home range and categories typically used in resource selection studies (e.g., forest, crop). Similar to differences in size of home range by season, we also found that Akaike weights varied for growing and nongrowing seasons with global model receiving strong support $\left(\mathrm{AIC}_{\mathrm{c}}=0.99\right)$ for nongrowing season but not for growing season. For anthropogenic variables during the growing season, use of landscapes by deer was influenced more by landscape configuration (i.e., high interspersion of productive patches) than the variables included in the global model (i.e., combination of anthropogenic variables and configuration). More explanatory power by landscape configuration was likely a reflection of availability of natural forage occurring in multiple cover types during growing season (i.e., forest, grassland) and response to increased forage availability within edges (Whitney and Somerlot 1985; Pogue and Schnell 2001; Kie et al. 2002).

While previous research indicated an arbitrary buffer distance (i.e., extent) around locations or a home-range centroid would be inappropriate for assessing range size across regions, our data suggested that deer populations across the Midwest occupy landscapes at a similar size (i.e., home-range size). Influence of connectivity and selection of landscape variables by deer on home range varies depending on buffer sizes around animal locations that have been traditionally chosen to represent different spatial scales for studies on ungulates (Kie et al. 2002; Anderson et al. 2005). Furthermore, using buffers to define spatial scales becomes more problematic in comparisons of size of home range at multiple study sites because some species occupy sites to various extents (i.e., total area that the organisms encompass; Anderson et al. 2005). Unless all study sites are a minimum size to encompass the largest diameter buffer around a location or homerange centroid, use of buffered circles to delineate multiple spatial scales should be avoided. Furthermore, organisms do not perceive their environment as a grid of multiple land cover categories, such as our anthropogenic grain, and connectivity of landscapes plays an important role in determining how organisms respond to their environment (Fig. 3; Wiens 1976; Kotliar and Wiens 1990; Girvetz and Greco 2007). Our landscape connectivity framework enabled us to model our landscapes that were based less on habitat patch type and size (i.e., anthropogenically defined landscapes) and more on connectivity of highly selected patches and should be the focus of future landscape-level analysis of deer and possibly other species.

Our landscape connectivity framework resulted in a landscape of interconnected patches as perceived by deer as they move through the landscape. Results from our home ranges on connected landscapes identified areas of the landscape used by most deer on each study site. As we increased our spatial grain, connectivity of the landscape increased and locations of home ranges of deer occurred in cover types that were most connected (see Fig. 4 as an example). Roads have been documented to be a mortality source of deer (Finder et al. 1999; Hubbard et al. 2000; Etter et al. 2002) and roads concealed within forested cover types may not contribute to fragmentation as perceived by deer and hence, not influence their habitat use or movements substantially. For this reason, assessing landscape configurations in terms of connectivity of preferred cover types, as opposed to our anthropogenic spatial grain, may be more appropriate for assessing influence of landscape configuration on size of deer home range. Changes in model selection and Akaike weights by landscape connectivity reflected the tendency of deer to occupy areas of high connectivity that included predominately 


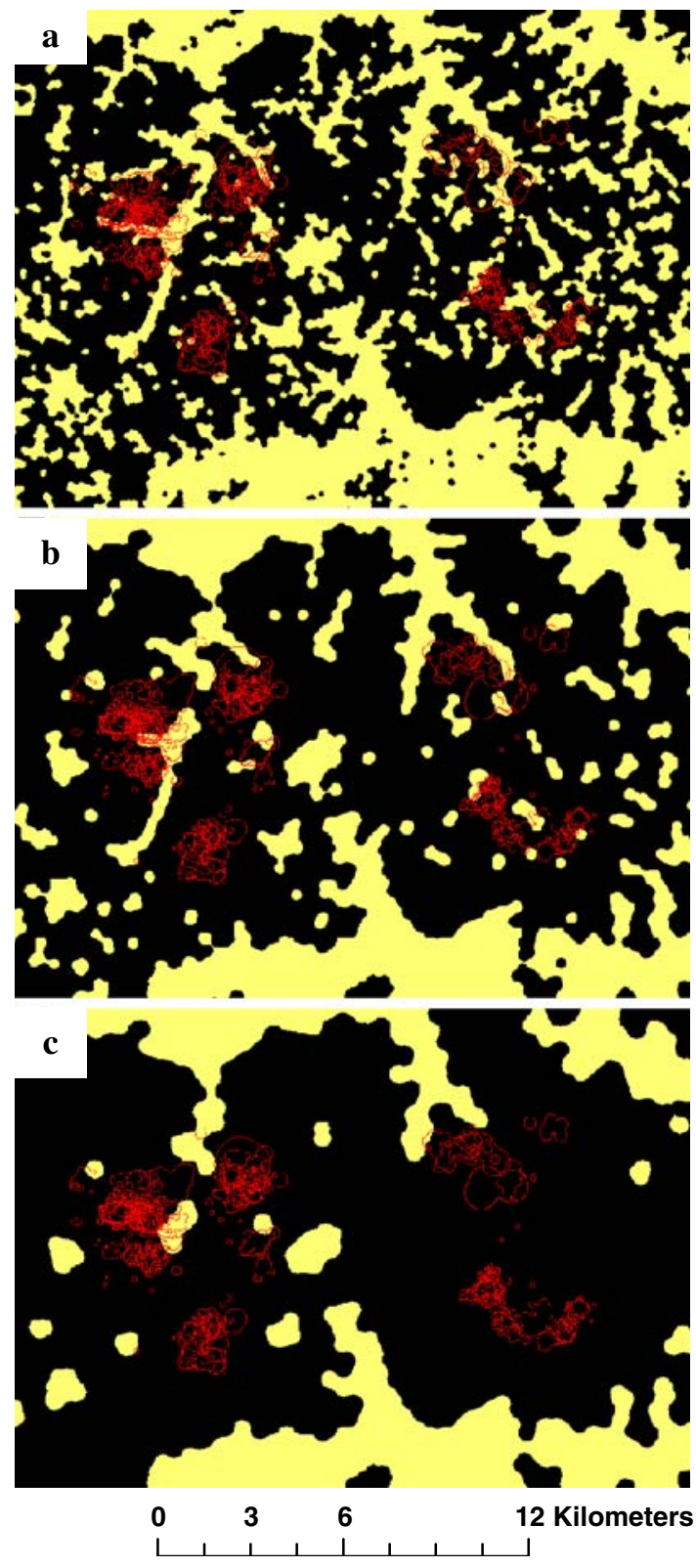

Fig. 4 Example of the spatial grains of analysis for home ranges of female white-tailed deer (red polygons) in Wisconsin using PatchMorph to represent the landscape at a low, b medium, and $\mathbf{c}$ high connectivity as perceived by the organism (Girvetz and Greco 2007). Black is habitat suitability of $>50 \%$ (i.e., forest, shrub) and yellow is habitat suitability $\leq 50 \%$ (i.e., grassland, crop, roads) based on perception of deer and their ability to move through the landscape in more suitable patches

forested areas (Fig. 4). Use of landscapes with connected forest cover likely provides easier movement for deer because forests provide cover and shelter from inclement weather and disturbance by humans or predators (Montgomery 1963; Beier and McCullough 1990; Grund et al. 2002). Furthermore, without spatial connectivity and associated corridors, use of suitable patches should decline with increasing isolation in the landscape (Milne et al. 1989; Turner 1989).

\section{Conclusions}

Model selection for variables that influence size of home range varied with landscape connectivity documenting that deer perceive landscapes differently than the availability of various cover types depicted in most space use analyses. The importance of high contrast edges (i.e., forest-agriculture) and connectivity of landscapes emphasizes that deer may be locally abundant over large areas across a landscape (i.e., $>500 \mathrm{~km}^{2}$ as in Michigan and Wisconsin) or more concentrated in exurban areas or isolated public lands $\left(<40 \mathrm{~km}^{2}\right.$ as in Illinois and Nebraska). Landscape connectivity varies widely across each site and identifying connectivity of this preferred matrix of forest and agricultural crops across landscapes is necessary to studies of disease epidemiology and response of deer to habitat change. Region-wide data (e.g., landcover types) are available as layers in GIS so ideal landscape configuration and connectivity models could be created in GIS and the use of buffers created from diameters of arbitrary distances should be avoided in comparisons of organisms across regions or ecosystems. Our results indicate that landscape configuration and connectivity should be considered in creating deer management units or when considering potential management problems associated with spatial variability in crop and property damage or disease transmission.

Acknowledgments Funds were provided by the State Agricultural Experiment Station (SAES) in partnership with the Cooperative State Research, Education, and Extension Service (CSREES) under the US Department of Agriculture and the National Wildlife Research Center of the United States Department of Agriculture, Animal and Plant Health Inspection Service, Wildlife Services. Funding and logistical support for Illinois was provided by the Illinois Department of Natural Resources through the Federal Aid Project W-87-R, and Cooperative Wildlife Research Laboratory, Department of Zoology, and Graduate School at Southern Illinois University Carbondale. Several people assisted with field work in Illinois, especially C. Bloomquist, M. Bloomquist, A. Nollman, 
P. McDonald, J. Rohm, and D. Storm. Funds for field work in Michigan were provided by the Michigan Department of Natural Resources-Wildlife Division through the Federal Aid in Restoration Act under Pittman-Robertson Project W-147-R, Michigan State University, Michigan Agricultural Experiment Station, Safari Club International, and Whitetails Unlimited. Several people contributed to the project and assisted with Michigan field work, especially T. Hiller with assistance from A. Leach, E. Arrow, R. Havens, B. Dodge, L. McNew, D. Haan, M. Rubley, B. Rudolph, S. Dubay, S. Hanna, F. Davis, and V. Tisch. Funds for field work in Nebraska were provided by the United States Fish and Wildlife Service, Desoto National Wildlife Refuge, Nebraska Game and Parks Commission, Safari Club International, Nebraska Bowhunters Association, Professional Bowhunters Association, Cabela's Incorporated, Berryman Institute for Wildlife Damage Management, and the University of Nebraska-Lincoln. We thank G. Gage, L. Klimek, M. Buske, B. Barry, and M. Sheets for providing study sites, equipment, assistance, maintenance, and lodging and G. Clements, M. Clements, S. Korte, and J. Gilsdorf for assistance with data collection in Nebraska. Funds for field work in Wisconsin were provided by the Wisconsin Department of Natural Resources, Wisconsin Cattleman's Association, Whitetails Unlimited Association, Northcentral Agricultural Experiment Station, Nelson Institute for Environmental Studies, College of Agriculture and Life Sciences, Department of Wildlife Ecology, Women in Science and Engineering Leadership Institute, and the University of Wisconsin-Madison Graduate School. Many people assisted with Wisconsin field work and analysis, especially: A. M. Oyer, L. H. Skuldt, J. C. Chamberlin, V. Green, W. Delanis, R. A. McLean, D. Grove, and S. B. Magle. We thank D. Theobald at Colorado State University for creating and providing the urban density GIS data layer used in this manuscript.

\section{References}

Anderson DP, Forester JD, Turner MG, Frair JL, Merrill EH, Fortin D, Mao JS, Boyce MS (2005) Factors influencing female home range sizes in elk (Cervus elaphus) in North American landscapes. Landscape Ecol 20:257-271. doi: 10.1007/s10980-005-0062-8

Beier P, McCullough DR (1990) Factors influencing whitetailed deer activity patterns and habitat use. Wildl Monogr 109:1-51

Blanchong JA, Joly DO, Samuel MD, Langenberg JA, Rolley RE, Sausen JF (2006) White-tailed deer harvest from the chronic wasting disease eradication zone in south-central Wisconsin. Wildl Soc Bull 34:725-731. doi:10.2193/00917648(2006)34[725:WDHFTC]2.0.CO;2

Brinkman TJ, DePerno CS, Jenks JA, Haroldson BS, Osborn RG (2005) Movement of female white-tailed deer: effects of climate and intensive row-crop agriculture. J Wildl Manage 69:1099-1111. doi:10.2193/0022-541X(2005)069 [1099:MOFWDE]2.0.CO;2

Burnham KP, Anderson DR (2002) Model selection and multimodel inference: a practical information-theoretic approach. Springer, New York
Campa H III, Winterstein SR, Peyton RB, Dudderar GR, Leeferes LA (1997) An evaluation of a multidisciplinary problem: ecological and sociological factors influencing white-tailed deer damage to agricultural crops in Michigan. Trans North Am Wildl Nat Resour Conf 62:431-440

Caughley G (1981) Overpopulation. In: Jewell PA, Holt S (eds) Problems in management of locally abundant wild mammals. Academic Press, New York, pp 7-19

Connelly NA, Decker DJ, Wear S (1987) Public tolerance of deer in a suburban environment: implications for management and control. Proc East Wildl Damage Contr Conf 3:207-218

Conner MM, Miller MW (2004) Movement patterns and spatial epidemiology of a prion disease in mule deer population units. Ecol Appl 14:1870-1881. doi:10.1890/03-5309

Deblinger RD, Wilson ML, Rimmer DW, Spielman A (1993) Reduced abundance of Immature Ixodes dammini (Acari: Ixodidae) following incremental removal of deer. J Med Entomol 30:144-150

Decker DJ, Gavin TA (1987) Public attitudes toward a suburban deer herd. Wildl Soc Bull 15:173-180

Elkie PC, Rempel RS, Carr AP (1999) Patch analyst user's manual: a tool for quantifying landscape structure. Ontario Ministry of Natural Resources, Northwest Science and Technology, Thunder Bay

Etter DR, Hollis KM, Ludwig DR, Chelsvig JE, Anchor CL (2002) Survival and movements of white-tailed deer in suburban Chicago, Illinois. J Wildl Manage 66:500-510. doi: $10.2307 / 3803183$

Felix AB, Walsh DP, Hughley BD, Campa HI, Winterstein SR (2007) Applying landscape-scale habitat-potential models to understand deer spatial structure and movement patterns. J Wildl Manage 71:804-810. doi:10.2193/2006-366

Finder RA, Roseberry JL, Woolf A (1999) Site and landscape conditions at white-tailed deer/vehicle collision locations in Illinois. Landsc Urban Plan 44:77-85. doi:10.1016/ S0169-2046(99)00006-7

Ford RG (1983) Home range in a patchy environment: optimal foraging predictions. Am Zool 23:315-326

Fuller MR, Millspaugh JJ, Church KE, Kenward RE (2005) Wildlife radiotelemetry. In: Braun CE (ed) Techniques for wildlife investigations and management. The Wildlife Society, Bethesda, pp 377-417

Gaughan CR, DeStefano S (2005) Movement patterns of rural and suburban white-tailed deer in Massachusetts. Urban Ecosyst 8:191-202. doi:10.1007/s11252-005-3265-5

Gese EM, Andersen DE, Rongstad OJ (1990) Determining homerange size of resident coyotes from point and sequential locations. J Wildl Manage 54:501-506. doi:10.2307/3809 665

Girvetz EH, Greco SE (2007) How to define a patch: a spatial model for hierarchically delineating organism-specific habitat patches. Landscape Ecol 22:1131-1142. doi:10.1007/ s10980-007-9104-8

Gladfelter HL (1984) Midwest agricultural region. In: Halls LK (ed) White-tailed deer ecology and management. Stackpole Books, Harrisburg, pp 427-440

Grund MD, McAninch JB, Wiggers EP (2002) Seasonal movements and habitat use of female white-tailed deer associated with an urban park. J Wildl Manage 66:123-130. doi: $10.2307 / 3802878$ 
Harden CD, Woolf A, Rosenberry J (2005) Influence of exurban development on hunting opportunity, hunter distribution, and harvest efficiency of white-tailed deer. Wildl Soc Bull 33:233-242. doi:10.2193/0091-7648 (2005)33[233:IOEDOH]2.0.CO;2

Henderson DW, Warren RJ, Cromwell JA, Hamilton RJ (2000) Responses of urban deer to a $50 \%$ reduction in local herd density. Wildl Soc Bull 28:902-910

Hiller TL (2007) Land-use patterns and population characteristics of white-tailed deer in an agro-forest ecosystem in south central Michigan. Dissertation, Michigan State University, East Lansing

Hooge PN, Eichenlaub B (1997) Animal movement extension in ArcView, Version 1.1. Alaska Biological Science Center, US Geological Survey, Anchorage

Hubbard MW, Danielson BJ, Schmitz RA (2000) Factors influencing the location of deer-vehicle accidents in Iowa. J Wildl Manage 64:707-713. doi:10.2307/3802740

Johnson BK, Kern JW, Wisdom MJ, Findholt SL, Kie JG (2000) Resource selection and spatial separation of mule deer and elk during spring. J Wildl Manage 64:685-697. doi: $10.2307 / 3802738$

Kie JG, Bowyer RT, Nicholson MC, Boroski BB, Loft ER (2002) Landscape heterogeneity at differing scales: effects on spatial distribution of mule deer. Ecology 83:530-544

Kilpatrick HJ, Spohr SM (2000) Spatial and temporal use of a suburban landscape by female white-tailed deer. Wildl Soc Bull 28:1023-1029

Kilpatrick HJ, Spohr SM, Lima KK (2001) Effects of population reduction on home ranges of female white-tailed deer at high densities. Can J Zool 79:949-954. doi:10.1139/cjz79-6-949

Kjaer LJ, Schauber EM, Nielsen CK (2008) Spatial and temporal analysis of contact rates in female white-tailed deer. J Wildl Manage 72:1819-1825. doi:10.2193/2007-489

Kotliar NB, Wiens JA (1990) Multiple scales of patchiness and patch structure: a hierarchical framework for the study of heterogeneity. Oikos 59:253-260. doi:10.2307/3545542

Long ES, Diefenbach DR, Rosenberry CS, Wallingford BD, Grund MD (2005) Forest cover influences dispersal distance of white-tailed deer. J Mammal 86:623-629. doi: 10.1644/1545-1542(2005)86[623:FCIDDO]2.0.CO;2

McGarigal K, Marks BJ (1995) FRAGSTATS: spatial pattern analysis program for quantifying landscape structure. General Technical Report PNW-351, US Forest Service, Corvallis

Miller R, Kaneene JB, Fitzgerald SD, Schmitt SM (2003) Evaluation of the influence of supplemental feeding of white-tailed deer (Odocoileus virginianus) on the prevalence of bovine tuberculosis in the Michigan wild deer population. J Wildl Dis 39:84-95

Milne BT, Johnston KM, Forman TT (1989) Scale-dependent proximity of wildlife habitat in a spatially-neutral Bayesian model. Landscape Ecol 2:101-110. doi:10.1007/BF00 137154

Montgomery GG (1963) Nocturnal movements and activity rhythms of white-tailed deer. J Wildl Manage 27:422-427. doi: $10.2307 / 3798516$

Multi-Resolution Land Characteristics Consortium [MRLC] (2009) National land cover database. <http://gisdata.usgs. gov/website/mrlc/viewer.htm>. Accessed 4 May 2007
Nixon CM, Hansen LP, Brewer PA, Chelsvig JE (1991) Ecology of white-tailed deer in an intensively farmed region of Illinois. Wildl Monogr 118:1-77

North Central Regional Association of State Agricultural Experiment Directors [NCRA] (2008) Landscape ecology of white-tailed deer in agro-forested ecosystems: a cooperative approach to support management. $<$ http://nimss. umd.edu/homepages/home.cfm?trackID $=2074>$. Accessed 4 May 2007

O'Brien DJ, Schmitt SM, Fitzgerald SD, Berry DE, Hickling GJ (2006) Managing the wildlife reservoir of mycobacterium bovis: The Michigan, USA, experience. Vet Microbiol 112:313-323. doi:10.1016/j.vetmic.2005.11.014

Odum EP, Kuenzler EJ (1955) Measurement of territory and home range size in birds. Auk 72:128-137

Owen-Smith N (2004) Functional heterogeneity in resources within landscapes and herbivore population dynamics. Landscape Ecol 19:761-771. doi:10.1007/s10980-0050247-2

Pogue DW, Schnell GD (2001) Effects of agriculture on habitat complexity in a prairie-forest ecotone in the southern great plains of North America. Agric Ecosyst Environ 87:287-298. doi:10.1016/S0167-8809(01)00150-5

Rice WR (1989) Analyzing tables of statistical tests. Evol Int J Org Evol 43:223-225. doi:10.2307/2409177

Rodgers AR, Carr AP (1998) HRE: the home range extension for ArcView $^{\text {TM}}$ : user's manual. Beta test version 0.9. Ontario Ministry of Natural Resources, Centre for Northern Forest Ecosystem Research, Thunder Bay

Said S, Servanty S (2005) The influence of landscape structure on female roe deer home-range size. Landscape Ecol 20:1003-1012. doi:10.1007/s10980-005-7518-8

Schmitt SM, Fitzgerald SD, Cooley TM, Bruning-Fann CS, Sullivan L, Berry D, Carlson T, Minnis RB, Payeur JB, Sikarskie J (1997) Bovine tuberculosis in free-ranging white-tailed deer from Michigan. J Wildl Dis 33:749-758

Seaman DE, Powell RA (1996) An evaluation of the accuracy of kernel density estimators for home range analysis. Ecology 77:2075-2085. doi:10.2307/2265701

Seaman DE, Millspaugh JJ, Kernohan BJ, Brundige GC, Raedeke KJ, Gitzen RA (1999) Effects of sample size on kernel home range estimates. J Wildl Manage 63:739-747. doi: $10.2307 / 3802664$

Skuldt LH, Mathews NE, Oyer AM (2008) White-tailed deer movements in a chronic wasting disease area in southcentral Wisconsin. J Wildl Manage 72:1156-1160. doi: 10.2193/2006-469

Slingenbergh J, Gilbert M, de Balogh K, Wint W (2004) Ecological sources of zoonotic diseases. Rev Sci Tech 23:467-484

Storm DJ, Nielsen CK, Schauber EM, Woolf A (2007) Space use and survival of white-tailed deer in an exurban landscape. $\mathrm{J}$ Wildl Manage 71:1170-1176. doi:10.2193/2006-388

Stout RJ, Stedman RC, Decker DJ, Knuth BA (1993) Perceptions of risk from deer-related vehicle accidents: implications for public preferences for deer herd size. Wildl Soc Bull 21:237-249

Theobald DM (2001) Land-use dynamics beyond the American urban fringe. Geogr Rev 91:544-564. doi:10.2307/3594740

Theobald DM, Miller JR, Hobbs NT (1997) Estimating the cumulative effects of development on wildlife habitat. 
Landsc Urban Plan 39:25-36. doi:10.1016/S0169-2046 (97)00041-8

Tscharntke T, Klein AM, Kruess A, Steffan-Dewenter I, Thies C (2005) Landscape perspectives on agricultural intensification and biodiversity - ecosystem service management. Ecol Lett 8:857-874. doi:10.1111/j.1461-0248.2005.00 782.x

Turner MG (1989) Landscape ecology: the effect of pattern on process. Annu Rev Ecol Syst 20:171-197. doi:10.1146/ annurev.es.20.110189.001131

United States Department of Agriculture (2002) National agricultural statistics service. <http://www.nass.usda.gov/ Data_and_Statistics/Quick_Stats/index.asp $>$. Accessed 18 May 2007

VerCauteren KC, Hygnstrom SE (1998) Effects of agricultural activities and hunting on home ranges of female whitetailed deer. J Wildl Manage 62:280-285. doi:10.2307/ 3802289
Walter WD, VerCauteren KC, Gilsdorf JM, Hygnstrom SE (2009) Crop, native vegetation, and biofuels: response of white-tailed deer to changing management priorities. J Wildl Manage 73:339-344. doi:10.2193/2008-162

Warren RJ (1997) Deer overabundance-special issue. Wildl Soc Bull 25:213-562

Whitney GG, Somerlot WJ (1985) A case study of woodland continuity and change in the American midwest. Biol Conserv 31:265-287. doi:10.1016/0006-3207(85)90071-0

Wiens JA (1976) Population responses to patchy environments. Annu Rev Ecol Syst 7:81-120. doi:10.1146/annurev.es. 07.110176.000501

Wobeser GA (2006) Essentials of diseases in wild animals. Blackwell, Ames

Worton BJ (1989) Kernel methods for estimating the utilization distribution in home-range studies. Ecology 70:164-168. doi: $10.2307 / 1938423$ 